\title{
VARIATIONS IN LEARNING METHODS; UPAYA DALAM MENCETAK PAKAR FIQH MELALUI PENGEMBANGAN PEMBELAJARAN KITAB KUNING DI MA'HAD ALY
}

\author{
Fathor Rozi \\ Universitas Nurul Jadid, Paiton, Probolinggo \\ fathorrozi330@gmail.com
}

\begin{abstract}
This study aims to analyze the efforts to produce fiqh experts through the development of the yellow book at Ma'had Aly at Pondok Pesantren Salafiyah Syafi'iyah Sukorejo Situbondo. This research uses a qualitative approach, it is used to find more in-depth information about the efforts to produce fiqh experts through the development of the yellow book, while the type of research used is a case study that is focused on a particular case to be carefully observed and analyzed to completion. The results showed that: the efforts made by Ma'had Aly were using varied methods and models by combining (classical) Islamic boarding school learning methods such as sorogan, bandongan, wetonan, etc. and learning models in higher education (modern) such as active learning, demonstrations, CTL, Problem Based Intruction, etc. The supporting factors are the support of caregivers, lecturers of Ma'had Aly consisting of masyaikhs and a conducive environment, and


the inhibiting factors are inadequate infrastructure and funds and the lack of focus of lecturers and supervisors in teaching at Ma'had Aly, Implications of developing the yellow book done by Ma'had Aly, it is possible that contemporary fiqh experts will be the successors of classical fuqaha.

Keywords : Variations in Learning Methods, Fiqh Expert, Development of Yellow Book Learning

\section{Pendahuluan}

Pendidikan adalah pemberi corak hitam putihnya perjalanan hidup manusia. Oleh sebab itu, ajaran Islam menetapkan bahwasanya pendidikan merupakan salah satu aktivitas yang wajib hukumnya untuk laki- laki maupun perempuan, serta berlangsung seumur hidup- sejak dari buaian sampai ajal tiba (Al-Hadits) - life long education ${ }^{1}$.

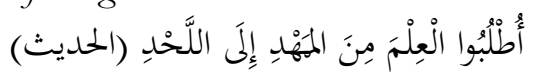

Belajarlah (carilah) ilmu mulai engkau dalam buaian (ayunan) sampai ke liang lahat. (al-Hadits) ${ }^{2}$

Pentingnya suatu pendidikan ialah untuk membentuk manusia seutuhnya bukan hanya diakui oleh dunia Islam saja, namun perihal ini diakui pula oleh bangsa Indonesia. Buktinya pasal 31 ayat 1 dan 2 yang berbunyi: 1) Setiap masyarakar negara berhak mendapatkan pendidikan. 2) Pemerintah berusaha dan menyelenggarakan satu sistem pendidikan nasional, yang diatur oleh undang- undang ${ }^{3}$.

Secara tidak langsung kedaulatan tersebut menempatkan pembelajaran selaku bagian yang tidak dapat dipisahkan dengan hidup dan kehidupan manusia ${ }^{4}$. Oleh sebab itu, pendidikan tetap memiliki pemikiran serta kajian, baik secara konseptual ataupun operasionalnya, sehingga diperoleh relevansi serta kepakaran menanggapi tantangan dan membongkar masalah yang dialami oleh umat manusia ${ }^{5}$.

\footnotetext{
${ }_{1}$ Zuhairini and Dkk, Filsafat Pendidikan Islam (Jakarta: Bumi Aksara, 1991).

${ }^{2}$ Haqqy, Tafsir Haqqy (Maktabah Syamilah), Juz 7.

3 Ketetapan Majelis Permusyawaratan Rakyat Republik. Indonesia Nomor IV/MPR/1999 Tentang: GBHN (Garis-Garis Besar Haluan Negara) Tabun 1999-2004 Beserta Perubahan Pertama Undang-Undang Dasar Negara Republik. Indonesia Tabun 1945 Beserta Susunan Kabinet Persat (Surabaya, 2004).

${ }^{4}$ Zuhairini and Dkk.

${ }^{5}$ Zuhairini and Dkk.
} 
Pendidikan adalah kebutuhan setiap umat manusia, agar dapat membentuk aspek- aspek setiap individu manusia. Adapun aspek tersebut meliputi: aspek keilmuan, aspek penguasaan, aspek kesenian serta aspek keagamaan. Dalam rangka pengembangan aspek itulah maka dibutuhkan lembaga- lembaga yang dapat menyalurkan serta memusatkan pendidikan yang cocok dengan kebutuhan manusia tersebut ${ }^{6}$.

Saat ini, lembaga pendidikan banyak sekali di temukan, baik yang terletak dijalur formal, nonformal ataupun informal. Adapun yang dimaksut pendidikan formal, nonformal ataupun informal yaitu sebagaimana berikut: Pertama, pendidikan formal terdiri atas pendidikan atau sekolah dasar, pendidikan menengah dan pendidikan tinggi. Kedua, Satuan pendidikan nonformal terdiri atas lembaga pelatihan, lembaga kursus, kelompok belajar, pusat kegiatan belajar warga, dan majelis taklim, dan satuan pendidikan yng lain. Ketiga, Kegiatan pendidikan informal yang dilakukan oleh keluarga dan lingkungan yang mengadakan aktivitas belajar secara mandiri ${ }^{7}$.

Pada umumnya, diantara berbagai macam lembaga pendidikan, pesantren lebih cocok dijadikan tolak ukur untuk lembaga- lembaga yang lain, perihal tersebut dikarenakan: Pertama, Pesantren tidaklah begitu membebankan dalam permasalahan pembiayaan kepada para peserta didiknya, walaupun terdapat sebagian pesantren yang mematok bayaran namun hal tersebut tidaklah membebani. Kedua, Pesantren, diniyah serta madrasah tersebut lebih banyak tumbuh di kawasan pedesaan dibandingkan yang tumbuh di perkotaan. Ketiga, Mengenai perihal tersebut sangatlah cocok sesuai tujuan utama pesantren sewaktu didirikan pada awal pertumbuhannya, yaitu: (a) membentuk santri yang memahami serta mendalami ilmu agama Islam maupun lebih diketahui dengan tafaqquh fi al- din, yang diharapkan bisa mencetak kader- kader ulama serta ikut mencerdaskan bangsa Indonesia, setelah itu diiringi dengan tugas. ( b) berdakwah dalam menyiarkan agama Islam. (c) benteng pertahanan umat dalam bidang akhlak. Sejalan dengan perihal inilah, materi pelajaran yang diajarkan di pondok pesantren seluruhnya terdiri dari pelajaran agama yang langsung digali dari kitab- kitab klasik yang menggunakan bahasa arab. Akibat berkembangnya zaman serta tuntutannya, tujuan pondok pesantren juga meningkat disebabkan peranannya yang

6 Didin Nurul Rosidin, 'Pesantren and Modernity in Indonesia: Ma'Had Aly of Kuningan', HUNAFA: Jurnal Studia Islamika, $9.2 \quad$ (2012), 219 <https://doi.org/10.24239/jsi.v9i2.74.219-244>.

7 Mulyani Mudis Taruna, 'Manajemen Pendidikan Ma'had Aly Di Lingkungan Pondok Pesantren; Kasus Ma'had Aly Hasyim Asy'ari Tebuireng, Jombang', EDUKASI: Jurnal Penelitian Pendidikan Agama Dan Keagamaan, 11.April 2013 (2013), 245-57. 
signifikan, tujuan yang dimaksud ialah. (d) berupaya menambah perkembangan masyarakat diberbagai zona kehidupan. Akan tetapi pada hakekatnya, ketiga tujuan terakhir merupakan perwujudan dari hasil yang dicapai pada tujuan awal, tafaqquh fi al- din ${ }^{8}$.

Bukan hanya menjadi lembaga yang membentuk moral, pesantren pun menjadi salah satu lembaga pendidikan yang menyajikan jalan keluar untuk para peserta didik serta orang tua dalam perihal memberikan pendidikan yang murah namun tidak kalah dengan lembaga-lembaga lain yang bermutu?

Pembentukan moral di pesantren tidaklah lepas dari sumber pelajaran serta model pembelajaran yang digunakan dalam proses pendidikan di pesantren. Sumber pelajaran yang terdapat dipesantren ialah Al- Qur' an, Hadits dan juga karya para ulama dahulu yaitu kitab kuning ${ }^{10}$.

Kitab kuning ialah sumber ilmu pengetahuan yang berharga bagi umat manusia, sebab banyak tokoh muslim yang menulis karya- karyanya kedalam wujud kitab kuning, misalnya: Ibnu Al- Haitham, Al- Mawardi, Ibnu Sina, Al- Ghazali. Ibnu Al- Haitham ialah seseorang fisikawan terkemuka serta sangat berjasa dibidang optik. Karyanya menampilkan kemajuan yang pesat dalam penggunaan tata cara eksperimental. Karya utamanya, Kitab Al-Manazir ( optik) ialah detesis ilmiah tentang mata. Al- Mawardi ialah seseorang yang banyak bergelut dengan dunia politik. Karya utamanya merupakan Kitab Al- Abkam Al- Sulthaniyah ( Kitab tentang Prinsip- Prinsip Pemerintahan), yakni suatu karya tentang etika serta Kitab Adab al-Dunya wa al- Din. Ibnu Sina sangat dikagumi sebab karyanya Kitab al-Sifa (kitab tentang pengobatan) yang didalamnya beliau membagi pengetahuan instan kedalam etika, ekonomi, politik dan pengetahuan teoritis kedalam fisika, matematika serta metafisika. AlGhazali, karya- karya utama Al- Ghazali yang lain merupakan Kitab Tahafut al- Falasifab (Kehancuran atau kesia- siaan maupun inkoherensi para filosuf). ${ }^{11}$

\footnotetext{
8 Abu Yazid, 'Pendidikan Tinggi Di Pesantren: Studi Kasus Ma'had Aly Situbondo', Jurnal Penelitian Pendidikan Agama Dan Keagamaan, 8.2 (2010), 3967-99.

9 Idham Idham, 'Pola Pengkaderan Ulama Di Sulawesi Selatan (Studi Pada Program Ma'had Aly Pondok Pesantren As'adiyah Sengkang Kabupaten Wajo)', Al-Ulum, 17.2 (2017), 439-58<https://doi.org/10.30603/au.v17i2.239>.

${ }^{10}$ Viki Amalia and Zainal Arifin, 'Kepemimpinan Nyai Dalam Memelihara Kajian Kitab Kuning Di Ma'had Aly Nurul Jadid Probolinggo', MANAGERIA: Jurnal Manajemen Pendidikan Islam, 3.2 (2018), 215-30 <https://doi.org/10.14421/manageria.2018.3201>.

11 Bugene A. Myers, Zaman Keemasan Islam, Para Ilmunan Muslim Dan Pengarubnya Terhadap Dunia Barat (Yogyakarta: Fajar Pustaka Baru, 2003).
} 
Pembelajaran kitab kuning menjadi sarana untuk menyalurkan serta mengkaji karya para ulama' serta cendikia muslim yang dicoba oleh berbagai pesantren sangatlah baik bagi pertumbuhan pemikiran serta perilaku generasi penerus islam dihari esok, misalnya: tentang masalah medis, generasi penerus islam bisa menekuni kitab karya dari Ibnu Sina, tentang permasalahan akhlak, generasi penerus islam bisa pula menekuni kitab karya imam Al- Ghazali tentang permasalahan Fiqh, generasi penerus islam bisa menekuni kitab karya imam Syafi' i $^{12}$, oleh karenanya metode pembelajaran kitab kuning yang terdapat di pesantren wajib lebih dimaksimalkan lagi dalam pengembangannya, supaya mampu melahirkan kader-kader yang pakar dalam berbagai bidang tertentu, lebih- lebih pakar dalam bidang Fiqh yang dapat meneruskan hukum syar'i yang dibawa oleh para madzhab yang empat.

Akan tetapi, pembelajaran kitab kuning tersebut akan menjadi kurang terencana serta kurang tepat sasaran, jikalau model pembelajaran yang digunakan dalam proses pembelajaran tersebut tidaklah tepat, misalnya: dalam penggunaan metode pembelajaran yang kurang cocok, penataan materi pelajaran yang kurang sistematis serta sedikitnya alokasi waktu ${ }^{13}$.

Kekurang terarahan serta kekurang tepatan proses pembelajaran kitab kuning tersebut dapat diatasi dengan metode para pendidik, baik itu: kyai, ustadz dan pihak- pihak yang berhubungan dengan proses pembelajaran terlebih dulu membuat perencanaan yang terpaut dengan materi pelajaran yang hendak diajarkan kepada para peserta didik ${ }^{14}$.

Selain itu hasil observasi awal sementara penulis saat melakukan silaturrahmi bincang-bincang santai dengan stake holder Ma'had Aly tersebut bahwa Pondok Pesantren Salafiyah-Syafi'iyah Sukorejo tersebut adalah lembaga pendidikan islam yang didirikan pada tahun 1908 oleh KHR. Syamsul Arifin. Beliau pengasuh dan pemimpin pesantren sukorejo selama 77 tahun karena pada tanggal 5 Maret 1951 beliau wafat. Kemudian kepemimpinan pesantren digantikan oleh putranya yaitu KHR.As'ad Syamsul Arifin.Pada masa kepemimpinan beliau perkembangan dan kemajuan pesantren sangat pesat.

\footnotetext{
12 Jurnal Pusaka, 'Pengkaderan Ulama Di Ma'had Aly Pondok Pesantren DDI Mangkoso Kabupaaten Barru Provinsi Sulawesi Selatan', 6.2 (2018), 183-96.

${ }^{13}$ Fathor Rozi and Ahmad Zubaidi, 'Efektivitas Penerapan Metode Al-Miftah Li AlUlum Dalam Belajar Membaca Buku Klasik Di PP. Nurul Jadid Paiton Probolinggo', Murobbi; Jurnal Ilmu Pendidikan, 3.2 (2019), 158-74.

${ }^{14}$ Heri Fadli and Antoni, 'MANAJEMEN PENDIDIKAN MA'HAD ALY (Studi Kasus Di Ma'had Aly Darul Hikmah Pondok Pesantren Nurul Hakim Kediri Lombok Barat NTB).', EL-HIKAM: Jurnal Pendidikan Dan Kajian Keislaman, Volume X, (2017).
} 
Berbagai lembaga pendidikan formal didirikan baik lembaga pendidikan agama maupun lembaga pendidikan umum, mulai tingkat dasar (pra sekolah) sampai perguruan tinggi.

Salah satunya lembaga yang berhasil dirintis di akhir hayatnya adalah $M a^{\prime}$ had $A l y$, yang memiliki tujuan yang mana tak lain adalah wasiat dari KH. Hasyim Asy'ari, yaitu menjadikan lembaga pendidikan terdepan untuk mencetak Generasi Faqibu Zamanibi (Pakar Fiqh Kontemporer). Sebuah Lembaga Pasca Pesantren pertama di Indonesia pada tanggal 21 Pebruari 1990, yang kemudian dikenal dengan Al-Ma'had Al-Aly Lil Ulum Al-Islamiyah Qism Al-Fiqh.

Ma' had Aly ialah suatu lembaga pendidikan Islam yang mengutamakan pada kajian permasalahan hukum formal syariah( Fiqh).

Mengapa harus Fiqh?. Sebab disamping bersumber pada wasiat KH. Hasyim Asy' ari, beliau mulai merasakan indikasi terdapatnya kelangkaan ulama yang memahami Fiqh secara utuh serta sanggup mengaplikasikannya dalam membongkar permasalahan kontemporer secara komprehenship dan bertanggungjawab.

Di lain sisi, Fiqh kerap dimengerti hanya sebatas standarisasi halalharam semata yang wajib diterima apa adanya tidak boleh di otak- atik dibanding selaku rujukan perilaku manusia dalam mengantarkan mereka pada kehidupan beragama, bermasyarakat secara baik serta bermutu. Eksesnya, Fiqh menjelma sebagai fitur undang- undang resmi yang rigid, tidak rasional serta tidak sanggup menyesuaikan diri dengan dinamika masyarakat. Ujung- ujungnya umat terus menerus menjauhkan dirinya dari jangkaun Fiqh. Salah satu buktinya, animo masyarakat khususnya dalam menguasai ilmu fiqh serta ilmu agama lainnya dalam skala luas terus menerus berkurang. Maka di sinilah Pondok Pesantren yang semenjak lahir memproklamirkan diri selaku lembaga pembelajaran tafaqquh fi al-din, mulai kehilangan identitasnya.

Masalah-masalah inilah yang ingin dijawab Kyai As'ad serta para ulama lainnya dengan mendirikan Ma' had Aly. Untuk mewujudkan tujuan tersebut, maka Ma'had Aly Pondok Pesantren Salafiyab-Syafi'iyah Sukorejo Situbondo memerlukan dan melakukan pengembangan pembelajaran kitab kuningnya, khususnya dalam aspek pengaplikasian, pendalaman dan pemahaman materi Fiqh serta upaya-upaya yang di lakukan Ma'bad Aly untuk para santrinya dalam mencetak Generasi Faqibu Zamanibi (Pakar Fiqh Kontemporer).

Dengan mengambil lokasi penelitian di Ma'had Aly Pondok Pesantren Salafiyah Syafi'iyah Sukorejo perlu dilakukan. Sebab Pesantren tersebut memiliki keunikan tersendiri yang tidak dimiliki oleh Pesantren lainnya. Pertama, Ada syarat tertentu untuk setiap santri yang ingin masuk lembaga nonformal yang terdapat di Ma'had Aly, minimal berumur 17 
tahun . Kedua, Latar belakang Santri yang dimiliki sangat beragam. Ketiga, Pokok kajiannya lebih cenderung pada ilmu Fiqh dan ushul Fiqh. Keempat, Kurangnya fokus santri ketika mempelajari materi Fiqh, sehingga tidak memahami tujuan atau arah pembelajaran yang sebenarnya. Mereka hanya fokus mengorek kitab mulai dari struktur kalimat, tata bahasa dan maksud teks kelima, Materinya berbasis kitab kuning. Keenam, Tidak adanya silabus dan rencana pembelajaran semester (RPS) yang jelas. Ketujuh, Fasih dalam membaca kitab kuning. Kedelapan, Kurang mampu dalam menguasai serta memahami isi kandungan dalam kitab.

Terdapat beberapa penelitian yang mengurai tentang pendidikan multikultural; Penelitian Teuku Zulkhairi \& Muzakir ${ }^{15}$ yang menyatakan bahwasanya kitab kuning menjadi fokus utama dalam pengembangan kurikulum. Pada tahapan perencanaan, penyusunan mata kuliah berbasis kitab kuning, kemudian penguasaan kitab kuning dijadikan sebagai keterampilan khusus lulusan.

Effendi Chairi ${ }^{16}$ juga menyatakan bahwa kesinambungan tradisi dan kemodernan dan hal tersebut sinkron dengan pemikirannya Abid alJabiri maupun kaidah ushul-fiqh_al-muhafadzatu, ala qadim alshalih, wa alabdzu bi al-jadid al-ashlah, adanya sesi diskusi di antara para santri yang tidak pernah terjadi sebelumnya karena sistemnya yang monolog, teachercentred, serta indoktrinatif.

Berangkat dari prmasalahan di atas, penulis termotivasi untuk mengadakan penelitian tentang pengembangan pembelajaran Kitab Kuning, Dalam perihal ini, peneliti fokus ingin mengkaji mulai pengembangan pembelajaran kitab kuning, yang mungkin akan meliputi pelaksanaan, metode atau model pengembangannya serta faktor pendukung dan penghambat pengembangannya sehingga bisa menjadikan para santri lebih menguasai lagi ilmu Fiqh yang akan menjadi topik pembahasan penelitian ini.

\section{KAJIAN TEORI \\ Pengembangan pembelajaran kitab kuning}

\footnotetext{
15 Teuku Zulkhairi and Muzakir, 'PENGEMBANGAN KURIKULUM BERBASIS KITAB KUNING PENDAHULUAN Salah Satu Perkembangan Mutakhir Dalam Dunia Pendidikan Islam Di Indonesia Dewasa Ini Adalah Hadirnya Ma ' Had Aly Sebagai Perguruan Tinggi Islam Khas Pesantren. Hal Ini Berdasarkan Peraturan Mente', MUDARRISUNA, 10.4 (2020), 539-51.

${ }^{16}$ Effendi Chairi, 'Pengembangan Metode Bandongan Dalam Kajian Kitab Kuning Di Pesantren Attarbiyah Guluk-Guluk Dalam Perspektif Muhammad Abid Al-Jabiri', Nidhomul Haq: Jurnal Manajemen Pendidikan Islam, 4.1 (2019), 70-89 $<$ https://doi.org/10.31538/ndh.v4i1.233>.
} 
Islam menggambarkan agama yang diturunkan oleh Allah melewati nabinya yang terpilih yaitu nabi Muhammad SAW yang dibekali dengan buku( kitab) suci yang bernama Al- Qur' an: sebuah buku yang mempunyai kandungan visi moral yang luar biasa ${ }^{17}$. Berawal dari kitab suci tersebut, dikemudian hari timbul banyak pemikiran, pengkajian serta penafsiran yang dicoba oleh para ulama dan para cendikia muslim. Alqur' an yang dari dahulu hingga hari ini berjumlah sama, tidak meningkat serta tidak pula menurun, sebagaimana firman Allah:

$$
\text { انا نحن نزلنا الذكر وانا له لحافظون (الحجر: 9 }
$$

"Sesunggubnya telah kami turunkan peringatan (Qur'an) dan sesunggubnya kami memeliharanya" (QS. Al-Hijr: 9) ${ }^{18}$.

Ternyata merupakan sumber pengetahuan yang sangat berarti serta tidak pernah ada habis- habisnya untuk dikaji, sebagai buktinya banyak karya dan pemikiran para ulama serta cendikia baik yang berasal dari dalam golongan kaum muslimin sendiri maupun dari luar golongan kaum muslimin, yaitu non muslim yang mengkaji kandungan yang terdapat didalam al-qur'an, yang tebalnya melebihi tebalnya kitab suci al-qur'an itu sendiri ${ }^{19}$.

Hasil pemikiran, pengkajian dan penafsiran para cendikia serta ulama muslim tadi, kemudian banyak yang diabadikan kedalam tulisan yang berbentuk buku atau kitab, sehingga karya- karya mereka senantiasa terpelihara serta dapat dinikmati oleh para generasi selanjutnya. Oleh karena itu, kitab kuning begitu penting untuk dipelajari karena kitab kuning merupakan khasanah keilmuan islam ${ }^{20}$. Sedangkan alasan lainnya mengenai perlunya pengkajian ataupun pembelajaran kitab kuning ialah: (1) sebagai pengantar untuk langkah ijtihad serta pembinaan hukum islam kontemporer. (2) sebagai pelajaran pokok dalam menguasai, menafsirkan serta mempraktikkan bagian hukum positif yang masih menempatkan hukum islam ataupun mazhab fikih tertentu selaku sumber hukum, baik secara historis ataupun secara resmi. (3) sebagai upaya agar dapat memenuhi kebutuhan umat manusia secara umum dengannmembagikan sumbangan untuk kemajuan ilmu hukum sendiri lewat riset perbandingan hukum( dirasah al- qanun al- muqaran) serta (4)

\footnotetext{
${ }^{17}$ Khaled Abou El-Fadl, Musyawarah Buku Menyusuri Keindahan Islam Dari Kitab Ke Kitab, Terj., Abdullah Ali (Jakarta: PT. Serambi Ilmu Semesta, 2002).

18 Al-Qur'an Al-Karim Dan Terjemabnya (Bandung: PT. Al-Ma'arif, 1989).

${ }^{19}$ Myers.

${ }^{20}$ Zulkhairi and Muzakir.
} 
sesuai dengan tujuan utama pengajian kitab-kitab kuning adalah untuk mendidik calon-calon ulama ${ }^{21}$.

\section{Pakar Fiqh}

Al-Fiqh secara etimologis berarti al-fahm yaitu pemahaman yang mendalam yang membutuhkan pengerahan potensi akal. Seperti yang diuraikan di atas, bahwa Fiqh adalah bagaimana kita memahami teks syariah, baik al-Quran dan as-Sunnah, sehingga dapat ditarik kesimpulan hukum. Dengan pengertian semacam ini, maka jelaslah jika di masa Rasulullah SAW telah terdapat fenomena Fiqh serta ilmunya.

Buktinya, tidak seluruh shahabat Nabi SAW merupakan seseorang yang mempunyai tingkatan pemahaman yang mendalam. Sebagian dari mereka merupakan orang- orang awam, yang tidak dapat begitu saja mengamalkan isi al- Quran, mereka bertanya terlebih dahulu kepada seseorang yang menjadi pakar Fiqh, baik kepada Rasulullah SAW ataupun para shahabat yang menguasai ilmunya.

Hanya sebagian saja dari shahabat Nabi SAW yang terhitung dalam golongan pakar Fiqh. Sebagiannya lagi walaupun senantiasa berstatus shahabat, namun tidak semuanta dikategorikan sebagai pakar di bidang ilmu Fiqh.

Yang amat utama tentu ialah keempat shahabat yang berperan sebagai khalifah rasyidah, ialah Abu Bakar Ash- Shiddiq, Umar bin AlKhattab, Ustman bin Al- Affan serta Ali bin Abi Thalib ridhwanullahi alaihim. Serta sebab kefaqihannyalah mereka dijadikan khalifaturasulillah.

Selain itu, ada pula Abdullah bin Al- Abbas, Abdullah bin Umar, Abdullah bin Masud dan Abdullah bin Amr bin Al- Ash. Meskipun mereka tidak menjadi khalifah, namun ilmu Fiqh mereka telah banyak mendapatkan pengakuan dari para shahabat dan tabiin setelah mereka.

Sedangkan Keterangan al-faqih yang ada di sebagian kitab adalah orang yg mempunyai kepakaran dalam menggali hukum dari beberapa sumbernya, pada akhirnya penyebutan al-faqih / al-mufti ini di kaitkan dg orang yang pakar dalam madzhab-madzhab ${ }^{22}$.

الفقيه أو المفتي: هو البحتهد، والمختهد هو: الذي حصلت له ملكة يقتدر بها على استنباط<smiles>[AsH2][AsH2][AsH2][AsH3]</smiles>

21 Akmal Bashori, 'Pengembangan Fikih Indonesia ( Studi Terhadap Kajian Fiqih Di Ma ' Had Aly Salafiyah Syafi' Iyyah Situbondo )', Jurnal Hukum Islam, 15.1 (2017), 49_ 72.

22 Wahbah Az-Zuhaili, Madẓab: Hukum2 Yang Ter-Cover Di Dlmmya Beberapa Masalah, Al-Fiqhul Islamy Wa Adillatuh. 
'Pakar Figh adalah: Mujtabid, sedangkan mujtabid itu adalab: seseorang yang memiliki kemampuan untuk mencetuskan bukumbukum dari dalil-dalilnya ${ }^{, 23}$

Inilah pengertian pakar Fiqh yang dikutip dari salah satu literatur kitab kuning, yang mungkin akan ada pengertian-pengertian lagi selain yang terterah di atas.

\section{HASIL DAN PEMBAHASAN}

Hasil penelitian menunjukkan bahwa; Upaya dalam Mencetak Pakar Fiqh melalui Pengembangan pembelajaran kitab kuning Di Ma'had Aly Pondok Pesantren Salafiyah Syafi'iyah Sukorejo Situbondo sebagai berikut;

\section{Upaya dalam Mencetak Pakar Fiqih melalui Pengembangan pembelajaran kitab kuning}

Berdasarkan hasil observasi yang peneliti dapatkan di lapangan, dan dokumen yang telah disajikan di atas, membuktikan bahwa Ma'had Aly Pondok Pesantren Sukorejo Situbondo yang memiliki tujuan "Menjadikan lembaga pendidikan terdepan untuk melahirkan Generasi Faqibu Zamanibi (pakar Fiqh kontemporer)"

Sebelum melaksanakan pengembangan pembelajaran kitab kuning terlebih dahulu dosen dan musyrif harus mempunyai pemahaman serta kemampuan tentang kitab kuning. Sehingga ketika berada dilapangan mereka sudah tidak mengalami kesulitan lagi untuk mengimplementasikan pengembangan pembelajaran kitab kuning dalam proses pembelajaran.

Untuk memberikan pengetahuan tentang pengembangan pembelajaran kitab kuning serta kemampuan untuk mengimplementasikannya maka dosen dan musrif Ma'had Aly mempunyai metode bervariasi dalam proses kegiatan belajar mengajar, semua diserahkan kepeda masyaikh, mu'allim dan mu'adzib dalam mengunakan metode ketika proses pembelajaran, ada yang menggunakan sorogan, bandongan, motola'ah sendiri, sistem muqoronah madahib dan metode lain yang menyesuaikan pengajarnya, selain itu juga ma'had aly mengadakan musyawarah kelompok, seminar, muhadharah, Batsul ma'il, pelatihan, muroja'ah yang terkait dengan kajian Fiqih dan Ushul Fiqih. Hal ini sesuai dengan pernyataan mudir Ma'had Aly.

Dari hasil interview tersebut memberikan informasi bahwa pengembangan pembelajaran kitab kuning di Ma’had Aly PP. Salafiyah Syafi'iyah Sukorejo situbondo menggunakan sistem metode dan model

${ }^{23}$ Wahbah Az-Zuhaili, Al-Fiqhul Islamy Wa Adillatuh, Jilid 3 (Lebanon, 1986).

90 Fathor Rozi - Variations in Learning Methods 
yang bervariasi yang tidak monoton dan mampuh mencetak kader pakar Fiqih kontemporer ${ }^{24}$.

Dalam mengembangkan pembelajaran kitab kuning di Ma'had Aly tersebut diawali dengan melakukan perencanaan-perancanaan (planing) yang kemudian diterapkan / dilaksanakan (actuiting) dalam proses pembelajaran kitab kuning. Kemudian pada tahap akhir pengurus melakukan evaluasi (evaluating) terhadap pelaksanaan pembelajaran tersebut yang semuanya termaktub di kurikulum Ma'had Aly. Hal ini sebagaimana diungkapkan mudir Ma'had Aly PP. Salafiyah Syafi'iyah Sukorejo situbondo ${ }^{25}$.

Untuk mata kuliah ushuliyah (pokok) dan musaidah (pendukung) di Ma'had Aly Sukorejo ini sebagian besar dosen dan musyrif sudah mampu mengimplementasikan pembelajaran dengan baik dan efektif dalam bentuk pengembangan pembelajaran kitab kuning.

Pengembangan pembelajaran kitab kuning itu tergantung kepada tipelogi pengajarnya yang bervariasi dalam proses pembelajaran, sebut saja Prof. Dr. M.H. Baharun, M.A, dosen Ma'had Aly yang berasal dari kota Apel Malang, dalam pengembangan metode pembelajaran yang beliau terapkan sifatnya student center, muridnya disuruh baca setelah itu diterangkan dengan baik dan benar, lain halnya lagi pengembangan yang di implementasikan oleh Na'ib Mudir ma’had Aly, yaitu KH. Afifuddin Muhajir, M.Ag, beliau termasuk salah satu jajaran pengasuh di Pondok Pesantren Salafiyah Syafi'iyah Sukorejo, dalam penerapan sistem pengembangan metode pembelajaran bersifat teacher center, semuanya dikendalikan oleh pengajar, beliau sendiri yang baca kitab setelah itu diterangkan, hal ini menandakan bahwa sistem metode atau model klasik masih dianut oleh sebagian dosen Ma'had Aly, ada lagi dosen yang menggunakan sistem keterangan pakai bahasa arab, yang mana lebih menekankan kepada penguasaan kitab kuning dalam berbahasa arab, hal ini dijalankan oleh KH. Abdillah Mukhtar dari Banyuwangi, kota paling timur pulau jawa, dan beberapa dosen Ma'had Aly yang lain yang tidak disebutkan semuanya oleh penulis dalam penelitian ini.

Selanjutnya pengembangan pembelajaran kitab kuning tersebut diimplementasikan sebagaimana pada umumnya secara variatif yang bergantung kepada dosen pengajarnya. Hal ini dapat diketahui setelah peneliti melakukan observasi lapangan. Peneliti mencoba mengamati proses KBM (Kegiatan Belajar Mengajar) kitab kuning di Ma'had Aly tersebut. Pada saat itu sedang berlangsung proses belajar mengajar dengan menggunakan model klasik (teacher center) dengan

\footnotetext{
${ }^{24}$ Wawancara dengan KH. Ach. Azaim Ibrahimy, MH.I, Mudir Ma'had Aly, 2020.

25 Wawancara dengan KH. Ach. Azaim Ibrahimy, MH.I, Mudir Ma’had Aly, 2020.
} 
menggunakan metode bandongan dengan gaya ceramah yang diampuh oleh KH. Afifuddin Muhajjir. Di mana seorang guru membaca, mengartikan selanjutnya menjelaskan isi kandungan dari kitab kuning yang dikaji, sedangkan santri secara berkelompok memaknai kitab kuningnya dan mendengarkan penjelasan guru yang sedang mengajar.

Sedangkan keesokan harinya Prof. Dr. M.H. Baharun, M.A, dosen Ma'had Aly yang berasal dari kota Apel Malang mempunyai jadual ngajar, dalam pengembangan pembelajaran yang beliau terapkan model modern (student center) dengan menggunakan metode yang diserahkan semuanya kepada santri (active learning), dalam istilah klasik dikenal dengan sebutan sorogan.

Bandongan adalah salah satu metode pengajaran tradisional yang digunakan untuk mengajarkan ilmu- ilmu agama serta ilmu pengetahuan yang lain. Hal tersebut disebut pengajaran tradisional sebab sistemnya yang monolog, top- down, serta indoktrinatif ${ }^{26}$. Metode bandongan menjadi metode yang terus digunakan didalam pesantren walaupun muatannya lebih rumit serta kurang praktis dibanding dengan muatan yang di surau ataupun di masjid. Oleh karenanya, metode bandongan juga dapat dikatakan metode tradisional. Akan tetapi, tidak sedikit golongan yang mengkritik keberlangsungan pesantren hari ini. Kritik tersebut mengindikasi adanya stagnasi keilmuan di pesantren. Terdapat banyak aspek yang dapat menimbulkan stagnasi tersebut, baik dulu ataupun saat ini. Salah satu yang hendak penulis kemukakan ialah lantaran kitab kuningnya yang klasik serta dikaji dengan memakai metode bandongan serta terkadang dengan metode sorogan. Sehingga yang terjadi ialah kebaradaan kitab kuning( apapun tipe kitabnya) seakan dipertahankan, tanpa kritik, serta karenanya dianggap final. Meski demikian, perihal itu telah disadari betul oleh golongan pesantren, sehingga kitab- kitab kuning( kutub al- turats) yang dipelajari dikala ini tidak sedikit yang baru( kutub al- mua" sirah) serta perannya dikira tidak lebih hanya sebagai produk budaya yang absah dikaji dengan metodemetode kontemporer. Salah satu metodenya ialah pengembangan dari metode bandongan ${ }^{27}$.

Tidak hanya itu, ada pula dosen yang mengaplikasikan pengembangan problem based intruction( pembelajaran yang bersumber pada dari permasalahan). Dalam perihal ini pengembangan pembelajarannya diterapkan oleh katib $\mathrm{Ma}$ ' had aly, dimana dalam

\footnotetext{
${ }^{26}$ Chairi.

27 Limas Dodi, 'METODE PENGAJARAN NAHWU SHOROF (Ber-Kaca Dari Pengalaman Pesantren)', Tafaqquh: Jurnal Penelitian Dan Kajian Keislaman, 1.1 (2013), 100$122<$ http://jurnal.iaibafa.ac.id/index.php/tafaqquh/article/view/6>.
} 
pembelajaran ini dosen mendorong santri agar mengumpulkan data yang cocok dengan kasus tersebut yang pastinya tidak lepas dalam koredor Fiqih, membuka seluruh kitab- kitab Fiqih yang merujuk kepada kasus yang telah disiapkan oleh dosen pengajar, perihal ini dicoba santri agar memperoleh penjelasan, pengumpulan informasi atau data, hipotesis, serta penyelesaian permasalahan.

Problem Based Instruction ialah metode atau pendekatan pengajaran yang menggunakan permasalahan keadaan nyata sebagai suatu konteks untuk mahasiswa agar belajar tentang metode berpikir kritis serta kepakaran pemecahan permasalahan, dan juga untuk mendapatkan pengetahuan serta konsep yang essensial dari materi pelajaran Dosen berpartisipasi dalam membangun pemahaman mahasiswa. Partisipasi dosen sebaiknya dibatasi pada kedudukan fasilitator serta mitra belajar mahasiswa, misalnya memicu serta menyajikan suasana berpikir untuk siswa pada permasalahan autentik dari suatu materi melalui pelaksanaan konsep serta fakta. Dengan dihadapkan pada keadaan belajar semacam ini, siswa memiliki kecenderungan untuk memberikan makna pada permasalahan serta peristiwa disekitarnya. Hal ini juga dapat memberikan gejala pada kepakaran berpikir yang dimiliki mahasiswa. Kecenderungan ini juga bisa menimbulkan rasa keingintahuan terhadap berbagai macam hal disekitarnya sehingga ada pemberian makna. Mengembangkan kemampuan inisiatif serta berpikir kritis dan kreatif akan dapat memusatkan mahasiswa agar menjadi orang yang mampu mengambil keputusan agar dapat membuat sebuah keputusan serta penyelesaian masalah $^{28}$.

Selanjutnya peneliti beralih kepada Pengambangan pembelajaran kitab kuning yang akan dilakukan musyrif dan menyampingkan pengembangan metode pembelajaran yang sudah diterapkan oleh para dosen, dalam hal ini musyrif pun bervariasi dalm membimbing mahasantrinya ketika proses pembelajaran,biasanya pendampingan oleh musyrif ini pada waktu jam-jam musyawarah, ada pula yang privat dalam kondisi tertentu, salah satu dalam pengembangannya menggunakan kajian pendekatan kontekstual, konsep belajarnya menghadirkan situasi nyata yang berbentuk permasalahan kedalam forum sehingga santri bisa mencari jawabannya dan mendorong santri membuat hubungan antara pengetahuan dan penerapannya dalam kehidupan mereka.

28 P Dwijananti and D Yulianti, 'Pengembangan Kemampuan Berpikir Kritis Mahasiswa Melalui Pembelajaran Problem Based Instruction Pada Mata Kuliah Fisika Lingkungan', Jurnal Pendidikan Fisika Indonesia, 6.2 (2010), 108-14 $<$ https://doi.org/10.15294/jpfi.v6i2.1122>. 
Model pembelajaran kontekstual (contekstual teaching and learning) ialah proses pembelajaran yang holistik dan bertujuan untuk memberikan bantuan untuk siswa agar dapat memahami materi pelajaran dan mengaitkannya dengan konteks kehidupan sehari-hari mereka( konteks individu, sosial dan kultural), sehingga siswa memiliki pengetahuan maupun kemampuan yang dinamis dan fleksibel agar dapat mengkonstruksi sendiri secara aktif pemahamannya. ${ }^{29}$

\section{Faktor Pendukung dan Penghambat Pengembangan Metode Pembelajaran Kitab Kuning}

Setiap pengembangan metode pembelajran mempunyai aspek pendukung serta penghambat dalam proses penerapannya. Termasuk dalam meningkatkan metode pembelajaran kitab kuning. Dari hasil riset yang yang telah peneliti lakukan, ditemukan beberapa faktor pendukung serta penghambat dalam pengembangan metode pembelajaran kitab kuning di Ma' had Aly Sukorejo Pondok Pesantren Salafiyah Syafi' iyah Situbondo.

1. Faktor pendukung pengembangan pembelajaran kitab kuning

Pertama, Support pengasuh, Salah satu aspek yang fundamental dalam mencetak kader pakar Fiqih kontemporer melalui pengembangan metode pembelajaran kitab kuning ialah dengan adanya support ataupun dorongan mental dari pengasuh Pondok Pesantren ${ }^{30}$.

Kedua, Dosen $\mathrm{Ma}$ ' had Aly terdiri dari para masyaikh, dalam meningkatkan pembelajaran kitab kuning dalam tiap penyampaian materi pelajaran di Ma' had Aly, maka diperlukan para pengajar yang betulbetul alim serta berpengaruhi atau berkarismatik dan memiliki SDM yang baik kala mengajar ${ }^{31}$. Bisa jadi dengan adanya pengajar semacam itu dapat memberikan dampak positif untuk mahasantri Ma' had Aly.

Ketiga, Lingkungan belajar yang kondusif, lingkungan yang terorganisir serta terkondisikan memiliki dampak positif untuk mahasantri yang berada di lembaga Ma' had Aly, dikarnakan tidak lain dalam proses pembelajarannya telah berada di zona yang fokus untuk kajian kitab. Dengan adanya lingkungan yang kondusif maka proses pembelajaran kitab kuning akan dapat menuaikan hasil yang memuaskan untuk para mahasantri di ma' had aly.

2. Faktor penghambat pengembangan pembelajaran kitab kuning

Pertama, Sarana prasarana, Sarana prasarana yang mencukupi sangat dibutuhkan dalam kegiatan belajar mengajar, sebab dengan

\footnotetext{
${ }^{29}$ Idrus Hasibuan, 'MODEL PEMBELAJARAN CTL', Logaritma, II.01 (2014), 1-12.

30 Wawancara dengan Dr. Abdul Jalal, M.Ag, Biro Akademik, 2020.

31 Wawancara dengan KHR. Ach. Azaim Ibrahimy, MH.I, Mudir Ma’had Aly, 2020.
} 
tersedianya sarana prasarana yang mendukung akan memudahkan dosen serta musyrif dalam mengajar serta membimbing. Namun di Ma'had Aly Sukorejo memiliki sarana prasarana yang kurang memadai, misalkan disana belum terdapat perpustakaan yang cukup untuk menunjang mahasantri sebagai tempat mencari referensi atau rujukan kitab dalam menjawab permasalahan, sehingga hal tersebut menjadikan faktor penghambat pengembangan metode pembelajaran kitab kuning. Hal ini dinilai kurang bisa menunjang untuk bisa menciptakan lingkungan bi'ah keilmuan ${ }^{32}$.

Kedua, Dana, tidak dapat sangkal lagi bahwasanya dana adalah salah satu faktor yang urgent dalam suatu lembaga institusi, terlaksananya pembelajaran dalam suatu lembaga bisa berjalan normal bila dananya terselesaikan, faktor inilah yang ada didalam Ma'had Aly dan menjadi sedikit penghambat pengembangan metode pembelajaran kitab kuning di Ma'had Aly.

Ketiga, Tidak fokusnya dosen dan pembimbing dalam mengajar, Dalam pengembangan metode pembelajaran kitab kuning juga membutuhkan kefokusan dari dosen dan pembimbing dalam mengajar, akan tetapi kenyataan yang ada dilapangan berbicara lain, dosen dan pembimbing tidak fokus menangani satu lembaga saja, hal ini yang menjadikan suatu penghambat dalam pengembangan pembelajaran kitab kuning di Ma'had Aly Sukorejo, dengan adanya pembimbing dan pengajar yang merangkap dalam suatu jabatan dalam institusi mengakibatkan tidak totalitas dalam mengawal suatu lembaga.

Inilah yang peneliti temukan dilapangan terkait dari faktor pendukung dan penghambat pengambangan metode pembelajaran dalam mencetak kader pakar Fiqih kontemporer di Ma'had Aly Sukorejo demi untuk menjadi penerus ulama' dan menjawab problema yang ada dimasyarakat.

\section{KESIMPULAN}

Upaya mencetak pakar Fiqh melalui pengembangan pembelajaran kitab kuning dalam di Ma'had Aly Pondok Pesantren Salafiyah Syafi'iyah Sukorejo Situbondo mengunakan metode dan model bervariatif dengan cara menggabungkan metode pembelajaran pesantren (klasik) semisal sorogan, bandongan, wetonan, dll. dan model pembelajaran di perguruan

\footnotetext{
32 Ara Hidayat and Rizka Dwi Seftiani, 'Strategi Pengembangan Kurikulum Dan Sarana Prasarana Ma'had Aly Pondok Quran Bandung', MANAGERLA: Jurnal Manajemen Pendidikan Islam, 3.2 (2019), 313-33 <https://doi.org/10.14421/manageria.2018.3206>.
} 
tinggi (modern) semisal active learning, demonstrasi, CTL, Problem Based Intruction (Pembelajaran Berdasarkan Masalah), dll.

Sedangkan Faktor yang mendukung pengembangan metode pembelajaran kitab kuning ini adalah support pengasuh, dosen Ma'had Aly yang terdiri dari para masyaikh dan lingkungan yang kondusif. Adapun faktor penghambat pengembangan metode pembelajaran kitab kuning diantaranya, belum memadainya sarana prasarana dan dana serta tidak fokusnya dosen dan pembimbing dalam mengajar di Ma'had Aly.

Implikasi pengembangan pembelajaran kitab kuning yang dilakukan oleh Ma'had Aly memungkinkan akan memunculkan pakar fiqih kontemporer sebagai penerus fuqaha' klasik. 


\section{DAFTAR PUSTAKA}

Akmal Bashori, 'Pengembangan Fikih Indonesia ( Studi Terhadap Kajian Fiqih Di Ma ' Had Aly Salafiyah Syafi' Iyyah Situbondo )', Jurnal Hukum Islam, 15.1 (2017), 49-72

Al-Qur'an Al-Karim Dan Terjemahnya (Bandung: PT. Al-Ma'arif, 1989)

Amalia, Viki, and Zainal Arifin, 'Kepemimpinan Nyai Dalam Memelihara Kajian Kitab Kuning Di Ma'had Aly Nurul Jadid Probolinggo', MANAGERIA: Jurnal Manajemen Pendidikan Islam, 3.2 (2018), 215-30 <https://doi.org/10.14421/manageria.2018.32-01>

Az-Zuhaili, Wahbah, Al-Fighul Islamy Wa Adillatub, Jilid 3 (Lebanon, 1986)

Chairi, Effendi, 'Pengembangan Metode Bandongan Dalam Kajian Kitab Kuning Di Pesantren Attarbiyah Guluk-Guluk Dalam Perspektif Muhammad Abid Al-Jabiri', Nidhomul Haq: Jurnal Manajemen Pendidikan Islam, $4.1 \quad$ (2019), $\quad 70-89$ $<$ https://doi.org/10.31538/ndh.v4i1.233>

Didin Nurul Rosidin, 'Pesantren and Modernity in Indonesia: Ma'Had Aly of Kuningan', HUNAFA: Jumal Studia Islamika, 9.2 (2012), $219<$ https://doi.org/10.24239/jsi.v9i2.74.219-244>

Dodi, Limas, 'METODE PENGAJARAN NAHWU SHOROF (BerKaca Dari Pengalaman Pesantren)', Tafaqqub: Jurnal Penelitian Dan Kajian Keislaman, 1.1 (2013), 100-122 <http://jurnal.iaibafa.ac.id/index.php/tafaqquh/article/view/6 $>$

Dwijananti, P, and D Yulianti, 'Pengembangan Kemampuan Berpikir Kritis Mahasiswa Melalui Pembelajaran Problem Based Instruction Pada Mata Kuliah Fisika Lingkungan', Jurnal Pendidikan Fisika Indonesia, 6.2 (2010), 108-14 $<$ https://doi.org/10.15294/jpfi.v6i2.1122>

El-Fadl, Khaled Abou, Musyawarah Buku Menyusuri Keindaban Islam Dari Kitab Ke Kitab, Terj., Abdullah Ali (Jakarta: PT. Serambi Ilmu Semesta, 2002)

Fadli, Heri, and Antoni, 'MANAJEMEN PENDIDIKAN MA'HAD ALY (Studi Kasus Di Ma'had Aly Darul Hikmah Pondok Pesantren Nurul Hakim Kediri Lombok Barat NTB).', ELHIKAM: Jurnal Pendidikan Dan Kajian Keislaman, Volume X, (2017)

Haqqy, Tafsir Haqqy (Maktabah Syamilah), Juг 7

Hasibuan, Idrus, 'MODEL PEMBELAJARAN CTL', Logaritma, II.01 (2014), 1-12

Hidayat, Ara, and Rizka Dwi Seftiani, 'Strategi Pengembangan 
Kurikulum Dan Sarana Prasarana Ma'had Aly Pondok Quran Bandung', MANAGERLA: Jurnal Manajemen Pendidikan Islam, 3.2 (2019), 313-33 <https://doi.org/10.14421/manageria.2018.3206>

Idham, Idham, 'Pola Pengkaderan Ulama Di Sulawesi Selatan (Studi Pada Program Ma'had Aly Pondok Pesantren As'adiyah Sengkang Kabupaten Wajo)', Al-Ulum, 17.2 (2017), 439-58 $<$ https://doi.org/10.30603/au.v17i2.239>

Ketetapan Majelis Permusyawaratan Rakyat Republik. Indonesia Nomor IV/MPR/1999 Tentang: GBHN (Garis-Garis Besar Haluan Negara) Tabun 1999-2004 Beserta Perubahan Pertama Undang-Undang Dasar Negara Republik Indonesia Tabun 1945 Beserta Susunan Kabinet Persat (Surabaya, 2004)

Myers, Bugene A., Zaman Keemasan Islam, Para Ilmuwan Muslim Dan Pengarubnya Terbadap Dunia Barat (Yogyakarta: Fajar Pustaka Baru, 2003)

Pusaka, Jurnal, 'Pengkaderan Ulama Di Ma'had Aly Pondok Pesantren DDI Mangkoso Kabupaaten Barru Provinsi Sulawesi Selatan’, 6.2 (2018), 183-96

Rozi, Fathor, and Ahmad Zubaidi, 'Efektivitas Penerapan Metode AlMiftah Li Al-Ulum Dalam Belajar Membaca Buku Klasik Di PP. Nurul Jadid Paiton Probolinggo', Murobbi; Jurnal Ilmu Pendidikan, 3.2 (2019), 158-74

Taruna, Mulyani Mudis, 'Manajemen Pendidikan Ma'had Aly Di Lingkungan Pondok Pesantren; Kasus Ma'had Aly Hasyim Asy'ari Tebuireng, Jombang', EDUKASI: Jurnal Penelitian Pendidikan Agama Dan Keagamaan, 11.April 2013 (2013), 245-57

Wahbah Az-Zuhaili, Madzhab: Hukum2 Yang Ter-Cover Di Dlmnya Beberapa Masalah, Al-Fiqhul Islamy Wa Adillatuh

Yazid, Abu, 'Pendidikan Tinggi Di Pesantren: Studi Kasus Ma'had Aly Situbondo', Jurnal Penelitian Pendidikan Agama Dan Keagamaan, 8.2 (2010), 3967-99

Zuhairini, and Dkk, Filsafat Pendidikan Islam (Jakarta: Bumi Aksara, 1991) Zulkhairi, Teuku, and Muzakir, 'PENGEMBANGAN KURIKULUM BERBASIS KITAB KUNING PENDAHULUAN Salah Satu Perkembangan Mutakhir Dalam Dunia Pendidikan Islam Di Indonesia Dewasa Ini Adalah Hadirnya Ma' Had Aly Sebagai Perguruan Tinggi Islam Khas Pesantren. Hal Ini Berdasarkan Peraturan Mente', MUDARRISUNA, 10.4 (2020), 539-51 